\title{
Effect of inland salt-affected soil on physiological and growth characters of Eucalypt tree (Eucalyptus camaldulensis Dehnh.)
}

\author{
S. Cha-um* and C. Kirdmanee
}

National Center for Genetic Engineering and Biotechnology(BIOTEC), National Science and Technology Development Agency (NSTDA), 113 Thailand Science Park, Paholyothin Road, Klong Luang, Pathumthani 12120, Thailand

\begin{abstract}
Eucalyptus tree is a high potential plant species as a deep root system for water absorption to prevent the salt rise-up, a large bushy to cover the surface area and to detoxify the toxic salt ions. The aim of this research is to investigate the responses of Eucalyptus camaldulensis to different sites of inland salinity. Survival percentage of salt-stressed eucalypt was decreased, relating to salt contamination and negatively correlated with proline accumulation. Water use efficiency in the salt-stressed leaves was negatively related to electro conductivity (EC) values in the salt-affected soil. Chlorophyll a $\left(\mathrm{Chl}_{\mathrm{a}}\right)$ and total chlorophyll (TC) degradations were positively related to maximum quantum yield of photosystem II (PSII) $\left(\mathrm{F}_{\mathrm{v}} / \mathrm{F}_{\mathrm{m}}\right)\left(\mathrm{r}^{2}=0.89\right)$ and quantum efficiency of PSII $\left(\Phi_{\text {PSII }}\right)\left(r^{2}=0.95\right)$, leading to low net photosynthetic rate $\left(\mathrm{P}_{n}\right)\left(r^{2}=0.79\right)$ and to reduce the growth characteristics in term of plant height and circumstance. The survived eucalypt plants in the severe salinity land containing high salt contamination (1.7-2.0\% salt) may be further applied as potential plant species to remediate the inland salinity soil.
\end{abstract}

Keywords: chlorophyll a fluorescence, electro conductivity, eucalyptus, growth, netphotosynthetic rate, photosynthetic pigments, salinity

\section{تأثير التربة بالمناطق الداخلية المتأثرة بالملوحة على وظائف الفسيولويجة وخصائص

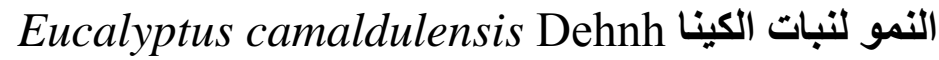

$$
\text { اس ـ شا-ام* و سى. كيريمانيي }
$$

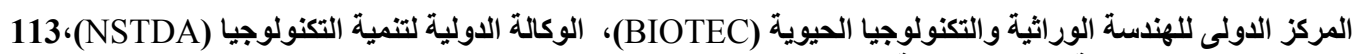

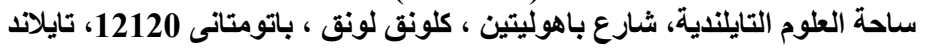

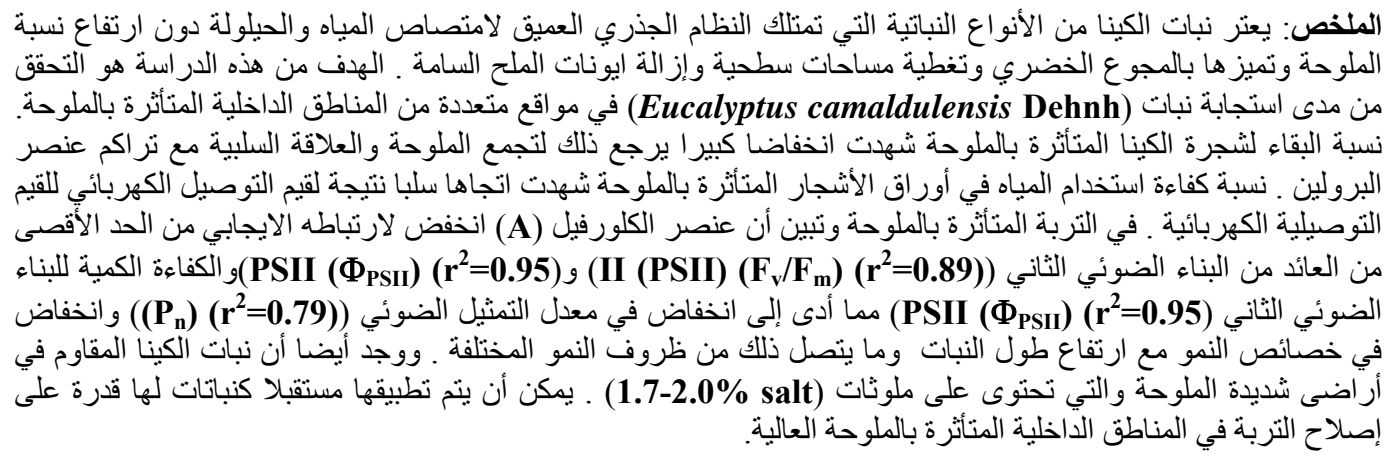

* Correspondence Author, Email: suriyanc@biotec.or.th 


\section{Introduction}

Salt affected soil is one of environmental issues to become a serious problem, inhibiting plant growth and development prior to loss of productivity, especially in crop species being defined as glycophyte (Hasegawa et al., 2000; Qadir et al., 2008). Salt affected soils (EC $>4$ dS $\mathrm{m}^{-1}$ ) can be characterized by the excess levels of water-soluble salts, including sodium chloride $(\mathrm{NaCl})$, sodium sulfate $\left(\mathrm{Na}_{2} \mathrm{SO}_{4}\right)$, calcium chloride $\left(\mathrm{CaCl}_{2}\right)$ and magnesium chloride $\left(\mathrm{MgCl}_{2}\right)$, among others. Those salts are easily water soluble and played as a positive charge i.e. $\mathrm{Na}^{+}$, $\mathrm{Ca}^{2+}, \mathrm{Mg}^{2+}$, and $\mathrm{K}^{+}$, and a negative charge i.e. $\mathrm{Cl}^{-}, \mathrm{SO}_{4}{ }^{2-}, \mathrm{HCO}^{3-}, \mathrm{CO}_{3}{ }^{2-}$, and $\mathrm{NO}_{3}{ }^{-}$ (Tanji, 2002). In inland salinity, $\mathrm{NaCl}$ is a dominant salt contamination in the soil. It is a small molecule when oxidized by water, producing sodium ions $\left(\mathrm{Na}^{+}\right)$and chloride ions $\left(\mathrm{Cl}^{-}\right)$, which are easily absorbed by the root tissues of higher plants and transferred to the whole plant using xylem uploading channels (Maathuis and Amtmann, 1999; Tester and Davenport, 2003; Rodriguez-Navarro and Rubio, 2006). In susceptible plant species, ionic and osmotic stresses derived from salt ions at the cellular level have been evidently identified (Mansour and Salama, 2004; Chinnusamy et al., 2005). There are many procedures that can be used to improve salt affected land, such as, water leaching, chemical remediation and phytoremediation (Ahmad and Chang, 2002; Sharma and Minhas, 2005; Qadir et al., 2007). A phytoremediation technique is an effective way to solve the saltaffected soil problem (Turner and Ward, 2002; Qadir and Oster, 2004; Qadir et al., 2007; Jianfeng et al., 2008; Kiliç et al., 2008).

Eucalyptus camaldulensis is an original species from Australia and widely distributed in many regions of the world with a short rotation (Rockwood et al., 2008) for pulp and paper production. It is a miracle plant to be grown in the drought and saline soil conditions (Madsen and
Mulligan, 2006; Dale and Dieters, 2007). The objective of present study was to investigate the adaptabilities including survival percentage, proline accumulation, photosynthetic abilities and growth performances as indicator of eucalypt tree in the salt-affected soil.

\section{Materials and methods}

\section{Plant materials}

Eucalyptus plantlets were propagated and photo-autotrophically acclimatized, according to Cha-um et al. (2003). The plantlets were directly transplanted to open plastic bags $($ size $10 \mathrm{~W} \times 10 \mathrm{~L} \times 20 \mathrm{H} \mathrm{cm})$, containing a mixture of two parts of soil and one part of vermiculite. The transplanted plantlets were incubated in a glasshouse at $30 \pm 2^{\circ} \mathrm{C} \quad 75 \pm 5 \%$ relative humidity (RH) and $500 \pm 100 \mu \mathrm{mol} \mathrm{m} \mathrm{m}^{-2} \mathrm{~s}^{-1}$ photosynthetic proton flux density (PPFD) by natural light intensity at plant level with $10 \mathrm{hd}^{-1}$ photoperiod. Six-month-old transplanted plantlets were acclimatized by irrigation with $50 \mathrm{mM} \mathrm{NaCl}$ and $50 \%$ shading natural light intensity for 7 days and then directly planted in salinity field trials, plot site I, II and III at Ban Muang $\left(17^{\circ} 5^{\prime} 0^{\prime \prime} \mathrm{N} \quad 103^{\circ} 35^{\prime} 0^{\prime \prime} \mathrm{E}\right)$ Sakol Nakron, Northeastern region of Thailand in different salt levels, $0.0-0.1 \%$ (control) and/or $1.7-2.0 \%$ salt $(291-342 \mathrm{mM} \mathrm{NaCl})$ (Table 1). Survival percentage, proline content, chlorophyll content, chlorophyll $a$ fluoresceence, photosynthetic abilities and growth performances were measured after planted in the field trial for 10 months.

The proline content of the leaves was extracted and analyzed according to the method of Bates et al. (1973). Fiftymilligrams of leaf materials were ground in liquid nitrogen using mortar. The homogenate powder was mixed with $1 \mathrm{~mL}$ aqueous sulfosalicylic acid (3\% w/v) and filtered through filter paper (Whatman \#1, England). The extracted solution was reacted with an equal volume of glacial acetic acid and ninhydrin reagent $(1.25 \mathrm{mg}$ ninhydrin in $30 \mathrm{~mL}$ glacial acetic acid and $20 \mathrm{~mL} 6 \mathrm{M} \mathrm{H}_{3} \mathrm{PO}_{4}$ ) and incubated at $95^{\circ} \mathrm{C}$ 
for $1 \mathrm{~h}$. The reaction was terminated by placing the container in an ice bath. The reaction mixture was mixed vigorously with $2 \mathrm{~mL}$ toluene. After cooling to $25^{\circ} \mathrm{C}$, the chromophore was measured by spectrophotometer $\mathrm{DR} / 4000$ at $520 \mathrm{~nm}$ using L-proline as a standard.

Table 1. Salt concentration, electro conductivity (EC) and soil pH in salt-affected sites in Northern region of Thailand.

\begin{tabular}{llll}
\hline Plot site & $\begin{array}{l}\text { Salt } \\
(\mathbf{\%})\end{array}$ & $\begin{array}{l}\mathbf{E C} \\
\left(\mathbf{d S ~} \mathbf{~ m}^{-\mathbf{1}}\right)\end{array}$ & $\mathbf{p H}$ \\
\hline I & 0.1 & 2.1 & 5.87 \\
& 1.7 & 13.3 & 4.83 \\
II & 0.0 & 1.4 & 5.49 \\
& 1.8 & 13.4 & 4.53 \\
III & 0.1 & 3.7 & 5.58 \\
& 2.0 & 16.1 & 4.72 \\
\hline
\end{tabular}

Plot sites I, II and III are located on $17^{\circ} 5^{\prime} 0^{\prime \prime} \mathrm{N} 103^{\circ} 35^{\prime} 0^{\prime \prime} \mathrm{E}$ to produce sodium chloride as salt mining using sun dry technique.

Chlorophyll a $\left(\mathrm{Chl}_{\mathrm{a}}\right)$, chlorophyll b $\left(\mathrm{Chl}_{\mathrm{b}}\right)$ and total chlorophyll (TC) concentrations were determined following the method of Shabala et al. (1998) and the total carotenoids $\left(\mathrm{C}_{\mathrm{x}+\mathrm{c}}\right)$ concentration was determined following the method of Lichtenthaler (1987). One hundred milligrams of leaf material was collected and placed in a $25 \mathrm{~mL}$ glass vial, along with $10 \mathrm{~mL} 95.5 \%$ acetone, and blended using a homogenizer. The glass vials were sealed with parafilm to prevent evaporation, and stored at $4^{\circ} \mathrm{C}$ for $48 \mathrm{~h}$. $\mathrm{Chl}_{\mathrm{a}}$ and $\mathrm{Chl}_{\mathrm{b}}$ concentrations were measured using a UV-visible spectrophotometer at $662 \mathrm{~nm}$ and $644 \mathrm{~nm}$ wavelengths. The $C_{x+c}$ concentration was also measured by spectrophotometer at $470 \mathrm{~nm}$.

Chlorophyll $a$ fluorescence emission from the adaxial surface on the third leaf from the shoot tip was monitored using a Fluorescence Monitoring System (FMS 2; Hansatech Instruments Ltd., Norfolk, UK) in the pulse amplitude modulation mode, as previously described by Loggini et al. (1999). A leaf, adapted to dark conditions for $30 \mathrm{~min}$ using leaf-clips, was initially exposed to the modulated measuring beam of far-red light (LED source with typical peak at wavelength $735 \mathrm{~nm})$. Original $\left(\mathrm{F}_{0}\right)$ and maximum $\left(\mathrm{F}_{\mathrm{m}}\right)$ fluorescence yields were measured under weak modulated red light $\left(<0.5 \mu \mathrm{mol} \mathrm{m} \mathrm{m}^{-2} \mathrm{~s}^{-1}\right)$ with $1.6 \mathrm{~s}$ pulses of saturating light $\left(>6.8 \mu \mathrm{mol} \mathrm{m} \mathrm{m}^{-2} \mathrm{~s}^{-1}\right.$ PAR), and calculated using FMS software for Windows ${ }^{\circledR}$. The variable fluorescence yield $\left(F_{v}\right)$ was calculated by the equation, $\mathrm{F}_{\mathrm{m}}-\mathrm{F}_{0}$. The ratio of variable to maximum fluorescence $\left(\mathrm{F}_{\mathrm{v}} / \mathrm{F}_{\mathrm{m}}\right)$ was calculated as maximum quantum yield of PSII photochemistry. The photon yield of PSII $\left(\Phi_{\mathrm{PSII}}\right)$ in the light was calculated by $\Phi_{\mathrm{PSII}}$ $=\left(\mathrm{F}_{\mathrm{m}}{ }^{\prime}-\mathrm{F}\right) / \mathrm{F}_{\mathrm{m}}{ }^{\prime}$ after $45 \mathrm{~s}$ illumination, when steady state was achieved.

Net photosynthetic rate $\left(\mathrm{P}_{\mathrm{n}}\right)$, transpiration rate $\left(\mathrm{E} ; \mathrm{mmol} \mathrm{m} \mathrm{m}^{-2} \mathrm{~s}^{-1}\right)$ and stomatal conductance $\left(\mathrm{g}_{\mathrm{s}} ; \mathrm{mol} \mathrm{H}_{2} \mathrm{O} \mathrm{m}^{-2} \mathrm{~s}^{-1}\right)$ were measured using a Portable Photosynthesis System with an Infra-red Gas Analyser (IRGA; Model LI 6400, LI$\mathrm{COR}^{\circledR}$ Inc, Lincoln, Nebraska, USA). E and $g_{s}$ were measured continuously by monitoring the $\mathrm{H}_{2} \mathrm{O}$ content of the air entering and existing in the IRGA headspace chamber. Water use efficiency (WUE) of acclimatized plantlets was calculated by the ratio of $\mathrm{P}_{\mathrm{n}}$ to $\mathrm{E}$ (Cha-um et al., 2007). 
The experiment was arranged in a Completely Randomized Design (CRD) with 10 replications $(\mathrm{n}=10)$. Analysis of variance (ANOVA) was computed using the SPSS software (SPSS for Windows, SPSS Inc., USA), as well as means in each treatment were compared by the Least Significant Difference (LSD).

\section{Results and discussion}

Survival percentage of eucalypt tree in salt-affected soil was significantly dropped to 30,16 and $14 \%$, relating to $1.7,1.8$ and $2.0 \%$ salt concentrations, respectively (Figure 1). In contrast, proline contents in the leaf tissues of eucalypt were enriched

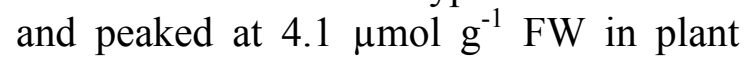
grown under $2.0 \%$ salt contamination in plot site III (Figure 1). The electro conductivity (EC) in the soil solution was negatively related to water use efficiency (Figure 2A). An increasing salt concentration in the soil solution directly injured the chlorophyll a $\left(\mathrm{Chl}_{\mathrm{a}}\right)$, chlorophyll b $\left(\mathrm{Chl}_{\mathrm{b}}\right)$, total chlorophyll (TC) and total carotenoids $\left(\mathrm{C}_{\mathrm{x}+\mathrm{c}}\right)$ contents (Table 2). As an example, the photosynthetic pigments, $\mathrm{Chl}_{\mathrm{a}}, \mathrm{Chl}_{\mathrm{b}}, \mathrm{TC}$ and $\mathrm{C}_{\mathrm{x}+\mathrm{c}}$ were significantly dropped when exposed to $1.70 \%$ salt conditions in plot site I for $54.79,53.75,54.50$ and $50.30 \%$, respectively. The $\mathrm{Chl}_{\mathrm{a}}$ and $\mathrm{TC}$ contents in the salt-stressed leaves was positively correlated with maximum quantum yield of PSII $\left(\mathrm{F}_{\mathrm{v}} / \mathrm{F}_{\mathrm{m}}\right)$ (Fig. 2B) and quantum efficiency of PSII ( $\Phi_{\text {PSII }}$ ) (Figure 2 C) respectively, causing to low net photosynthetic rate $\left(\mathrm{P}_{\mathrm{n}}\right)$ (Figure 2D). The $\mathrm{F}_{\mathrm{v}} / \mathrm{F}_{\mathrm{m}}, \Phi_{\text {PSII }}, \mathrm{P}_{\mathrm{n}}$ and stomatal conductance $\left(g_{s}\right)$ in the leaf tissues was significantly decreased by salt stress, whereas the different plot sites were unaffected (Table $3)$. In contrast, the transpiration rate $\left(g_{s}\right)$ in salt stressed leaves was enhanced. Diminishing of photosynthetic abilities including $\mathrm{F}_{\mathrm{v}} / \mathrm{F}_{\mathrm{m}}, \Phi_{\mathrm{PSII}}, \mathrm{P}_{\mathrm{n}}$ and $\mathrm{E}$ was depended on salt contamination in the soil and higher than those in control condition of all plot sites, leading to overall growth reduction. In the salt affected soil, growth performances including plant height and branch circumstance were significantly decreased (Figure 3 and Figure 4).

Table 2. Chlorophyll a $\left(\mathrm{Chl}_{\mathrm{a}}\right)$, chlorophyll b $\left(\mathrm{Chl}_{\mathrm{b}}\right)$, total chlorophyll (TC) and total carotenoids $\left(C_{x+c}\right)$ contents in the leaf tissues of eucalypt tree cultivated in different salt-affected sites for 10 months.

\begin{tabular}{|c|c|c|c|c|c|}
\hline Plot site & $\begin{array}{l}\text { Salt } \\
(\%)\end{array}$ & $\begin{array}{c}\mathrm{Chl}_{\mathbf{a}} \\
\left(\mu \mathrm{g} \mathrm{g}^{-1} \mathbf{F W}\right)\end{array}$ & $\begin{array}{c}\mathrm{Chl}_{\mathrm{b}} \\
\left(\mu \mathrm{g} \mathrm{g}^{-1} \mathbf{F W}\right)\end{array}$ & $\begin{array}{c}\text { TC } \\
\left(\mu \mathrm{g} \mathrm{g}^{-1} \mathbf{F W}\right)\end{array}$ & $\begin{array}{c}C_{x+c} \\
\left(\mu g^{-1} \mathbf{F W}\right)\end{array}$ \\
\hline \multirow[t]{2}{*}{ I } & 0.1 & $139.8 \mathrm{a}$ & $54.7 \mathrm{a}$ & $194.5 \mathrm{a}$ & $50.9 \mathrm{a}$ \\
\hline & 1.7 & $63.2 \mathrm{c}$ & $25.3 b$ & $88.5 \mathrm{c}$ & $25.3 \mathrm{c}$ \\
\hline \multirow[t]{2}{*}{ II } & $\mathbf{0 . 0}$ & $147.3 \mathrm{a}$ & $49.8 \mathrm{a}$ & $197.1 \mathrm{a}$ & $53.1 \mathrm{a}$ \\
\hline & 1.8 & $84.8 \mathrm{~b}$ & $31.7 \mathrm{~b}$ & $116.5 \mathrm{~b}$ & $33.4 \mathrm{~b}$ \\
\hline \multirow[t]{2}{*}{ III } & $\mathbf{0 . 0}$ & $133.7 \mathrm{a}$ & $49.3 \mathrm{a}$ & $183.0 \mathrm{a}$ & $48.3 \mathrm{a}$ \\
\hline & 2.0 & $72.4 b c$ & $26.7 \mathrm{~b}$ & $99.1 b c$ & $29.8 \mathrm{bc}$ \\
\hline \multicolumn{6}{|c|}{ Significant level } \\
\hline \multicolumn{2}{|c|}{ Plot site } & $* *$ & NS & $* *$ & $* *$ \\
\hline \multicolumn{2}{|l|}{ Salt } & $* *$ & $* *$ & $* *$ & $* *$ \\
\hline \multicolumn{2}{|c|}{ Plot site $\times$ Salt } & $* *$ & $*$ & $* *$ & $* *$ \\
\hline
\end{tabular}

Different letters in each column show significant difference at $p \leq 0.01\left(^{* *}\right)$ by Least Significant Difference (LSD). ${ }^{\text {NS }}$ and $*$ are represented non significant and significant at $p \leq 0.05$, respectively.

Survival percentage and physiological adaptabilities of eucalypt tree in the saltaffected soil were reduced relating to salt concentrations in the soil. Similarly, the survival percentage of eucalypt (E. camaldulensis) in the salt-affected soil is reduced to $87.6,72.4$ and $70.5 \%$, depending on cultivation periods, 3,6 and 9 months, respectively (Shirazi et al., 2006). In addition, the survival percentage 
of E. camaldulensis cultivated in the 300 $400 \mathrm{mM} \mathrm{NaCl}$ is better than other species, including E. populnea and E. citriodora (Madsen and Mulligan, 2006). Proline content is enriched in E. camaldulensis treated with $100 \mathrm{mM} \mathrm{NaCl}$, relating to salt concentrations (50 and $100 \mathrm{mM} \mathrm{NaCl}$ ) and salt exposure times (Woodward and Bennett, 2005).

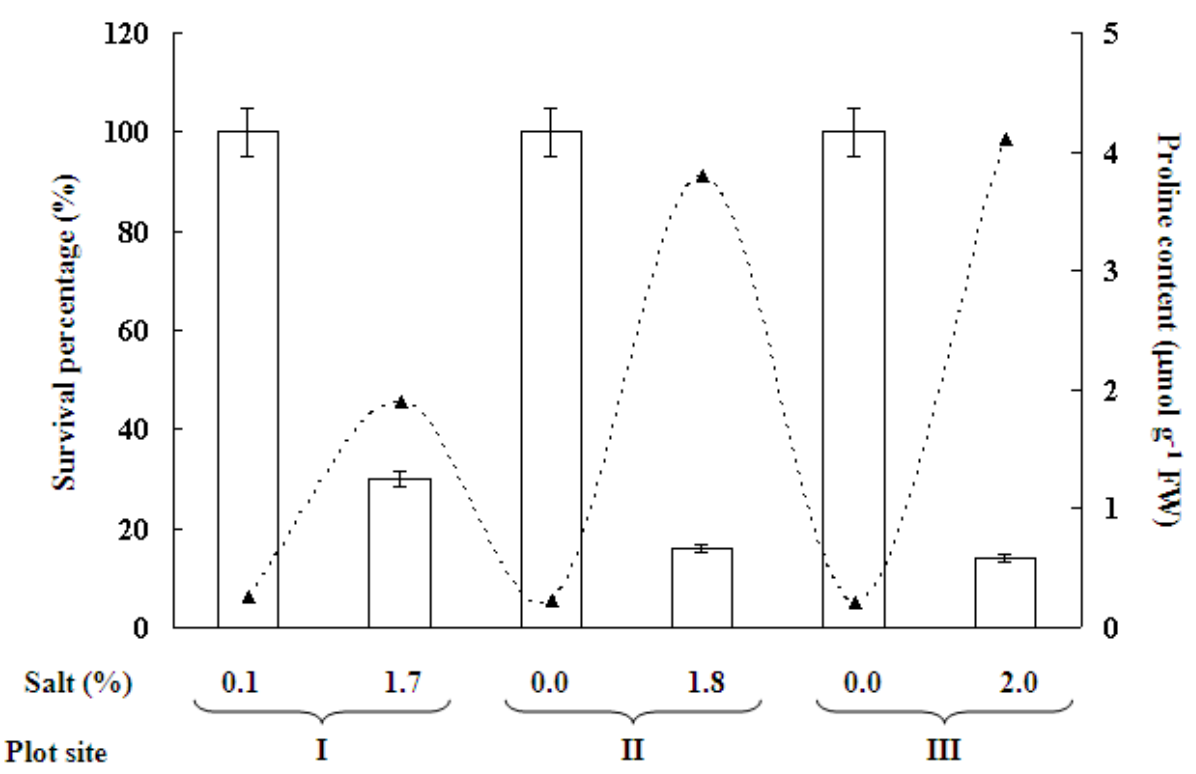

Figure 1. Survival percentage (white bar) and proline contents (dot line) in the leaf tissues of eucalypt tree cultivated in different salt-affected sites for 10 months.

Table 3. Maximum quantum yield of PSII $\left(\mathbf{F}_{\mathrm{v}} / \mathbf{F}_{\mathrm{m}}\right)$, photon yield of PSII $\left(\Phi_{\mathrm{PSII}}\right)$, net photosynthetic rate $\left(P_{n}\right)$ stomatal conductance $\left(g_{s}\right)$ and transpiration rate $(E)$ in the leaf tissues of eucalypt tree cultivated in different salt-affected sites for 10 months.

\begin{tabular}{|c|c|c|c|c|c|c|}
\hline Plot site & $\begin{array}{l}\text { Salt } \\
(\%)\end{array}$ & $\mathbf{F}_{\mathrm{v}} / \mathbf{F}_{\mathrm{m}}$ & $\Phi_{\text {PSII }}$ & $\begin{array}{l}P_{n} \\
\left(\mu \mathrm{mol} \mathrm{m}{ }^{-2} \mathrm{~s}^{-1}\right)\end{array}$ & 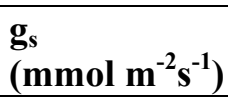 & $\begin{array}{l}\mathbf{E} \\
\left(\mathrm{mmol} \mathrm{m^{-2 }} \mathrm{s}^{-1}\right)\end{array}$ \\
\hline \multirow[t]{2}{*}{ I } & 0.1 & $0.834 \mathrm{a}$ & $0.785 \mathrm{a}$ & $8.53 \mathrm{~b}$ & $47.2 \mathrm{a}$ & $1.1 \mathrm{c}$ \\
\hline & 1.7 & $0.757 b$ & $0.633 b$ & $4.32 \mathrm{c}$ & $17.6 \mathrm{~b}$ & $2.9 \mathrm{a}$ \\
\hline \multirow[t]{2}{*}{ II } & 0.0 & $0.870 \mathrm{a}$ & $0.755 \mathrm{a}$ & $10.49 \mathrm{a}$ & $41.5 \mathrm{a}$ & $1.0 \mathrm{c}$ \\
\hline & 1.8 & $0.751 b$ & $0.665 b$ & $4.20 \mathrm{c}$ & $13.7 \mathrm{~b}$ & $2.5 \mathrm{a}$ \\
\hline \multirow[t]{2}{*}{ III } & 0.0 & $0.869 \mathrm{a}$ & $0.786 \mathrm{a}$ & $8.81 \mathrm{~b}$ & $36.6 \mathrm{a}$ & $0.9 \mathrm{c}$ \\
\hline & 2.0 & $0.761 b$ & $0.644 b$ & $3.36 \mathrm{c}$ & $14.5 \mathrm{~b}$ & $1.7 \mathrm{~b}$ \\
\hline \multicolumn{7}{|c|}{ Significant level } \\
\hline \multicolumn{2}{|l|}{ Plot site } & NS & NS & $* *$ & $* *$ & $* *$ \\
\hline \multicolumn{2}{|l|}{ Salt } & $* *$ & $* *$ & $* *$ & $* *$ & $* *$ \\
\hline \multicolumn{2}{|c|}{ Plot site $\times$ Salt } & * & ** & ** & $* *$ & ** \\
\hline
\end{tabular}

Different letters in each column show significant difference at $p \leq 0.01\left(^{* *}\right)$ by Least Significant Difference (LSD). ${ }^{\mathrm{NS}}$ and $*$ are represented non significant and significant at $p \leq 0.05$, respectively. 


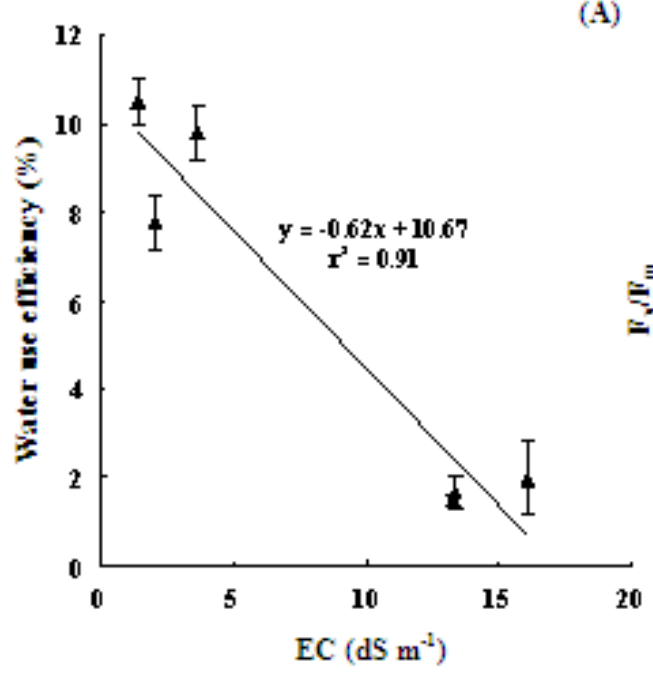

(C)

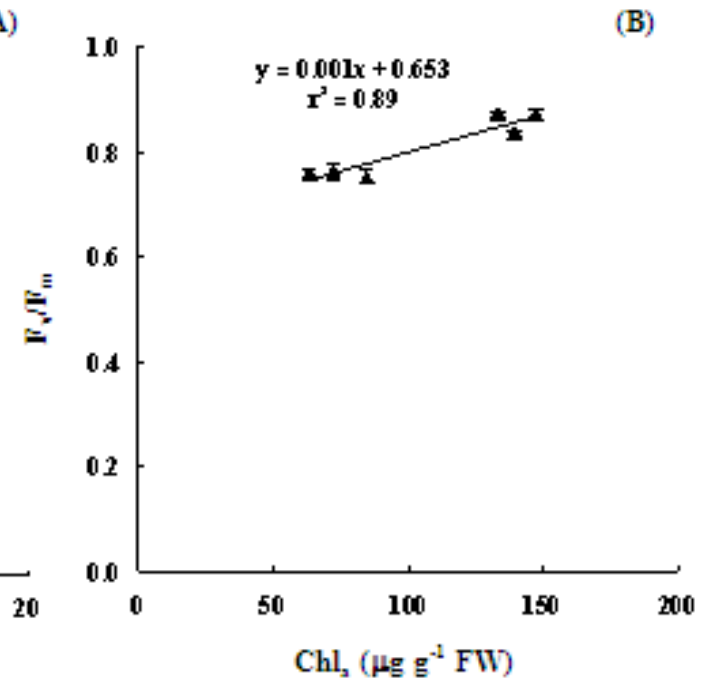

(D)
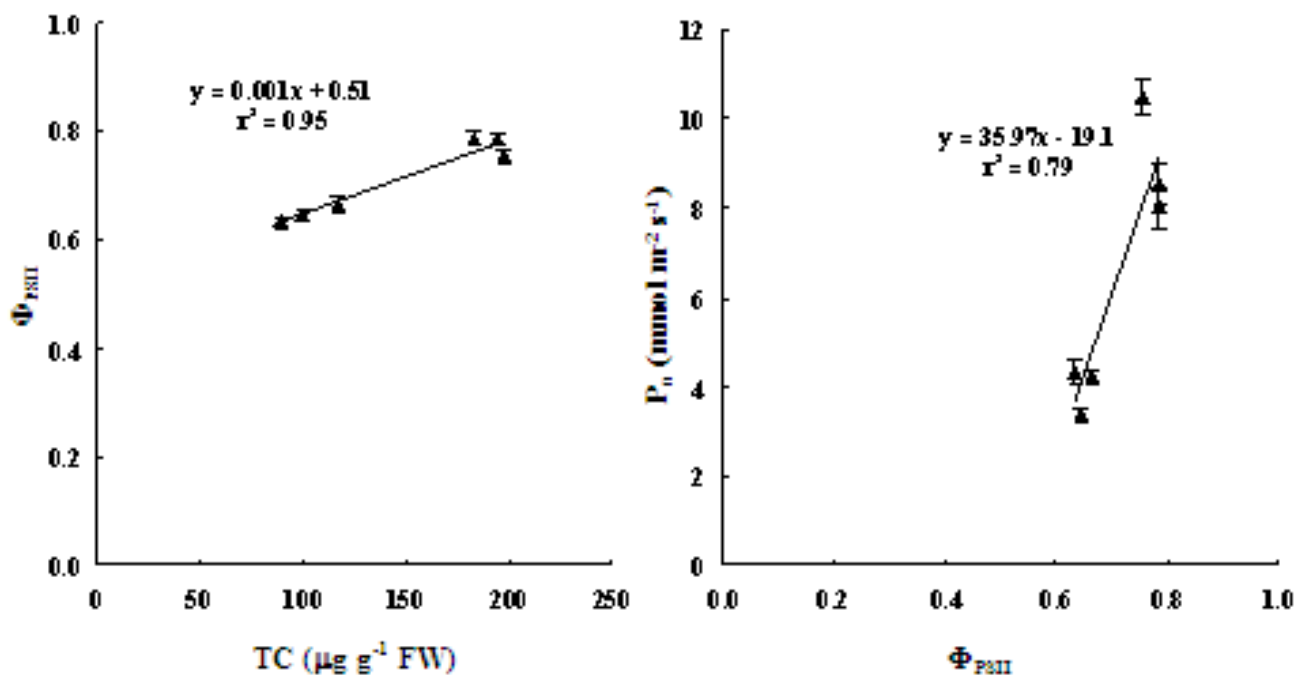

Figure 2. Relationships between electro conductivity in the soil and pigment content (A), chlorophyll a $\left(\mathrm{Chl}_{\mathrm{a}}\right)$ and maximum quantum yield $\left(\mathrm{F}_{\mathrm{v}} / \mathrm{F}_{\mathrm{m}}\right)(\mathrm{A})$, total chlorophyll (TC)and quantum efficiency of PSII ( $\left.\Phi_{\text {PSII }}\right)(B)$, quantum efficiency of PSII $\left(\Phi_{\mathrm{PSII}}\right)$ and net photosynthetic rate $\left(P_{n}\right)(C)$ in the leaf tissues of eucalypt tree cultivated in different salt-affected sites for 10 months.

The WUE in salt stressed eucalypt is significantly dropped, according to 100$300 \mathrm{~mol} \mathrm{~m}^{-3}$ sodium salt in the pot culture (Adams et al., 2005). Reduction of WUE may be played as a major toxic to be induced pigment degradation, chlorophyll $a$ fluorescence diminishing and netphotosynthetic rate $\left(\mathrm{P}_{\mathrm{n}}\right)$ reduction when exposed to salt stress. Chlorophyll contents in E. camaldulensis cultivated in pot culture containing salt are reduced (Rawat and Banerjee, 1998; Woodward and Bennett, 2005; Cha-um and Kirdmanee, 2008). Moreover, the chlorophyll $a$ fluorescence activities of chlorophyll pigments, including maximum quantum yield of PSII $\left(\mathrm{F}_{\mathrm{v}} / \mathrm{F}_{\mathrm{m}}\right)$ and quantum efficiency of PSII ( $\left.\Phi_{\text {PSII }}\right)$ are significantly diminished when exposed to salt-affected 
soil (Cha-um and Kirdmanee, 2008), leading to reduce $\mathrm{P}_{\mathrm{n}}$ with high $\mathrm{g}_{\mathrm{s}}$ (Rawat and Banerjee, 1998) and may play as effective criteria to identify the salt adaptabilities in eucalypt species (Corney et al., 2003). The reduction percentages of photosynthetic abilities are positively related to low biomass production i.e. plant height, diameter, number of leaves and plant dry weight (Rawat and Banerjee, 1998; Madsen and Mulligan, 2006; Chaum and Kirdmanee, 2008; Nasim et al., 2008).

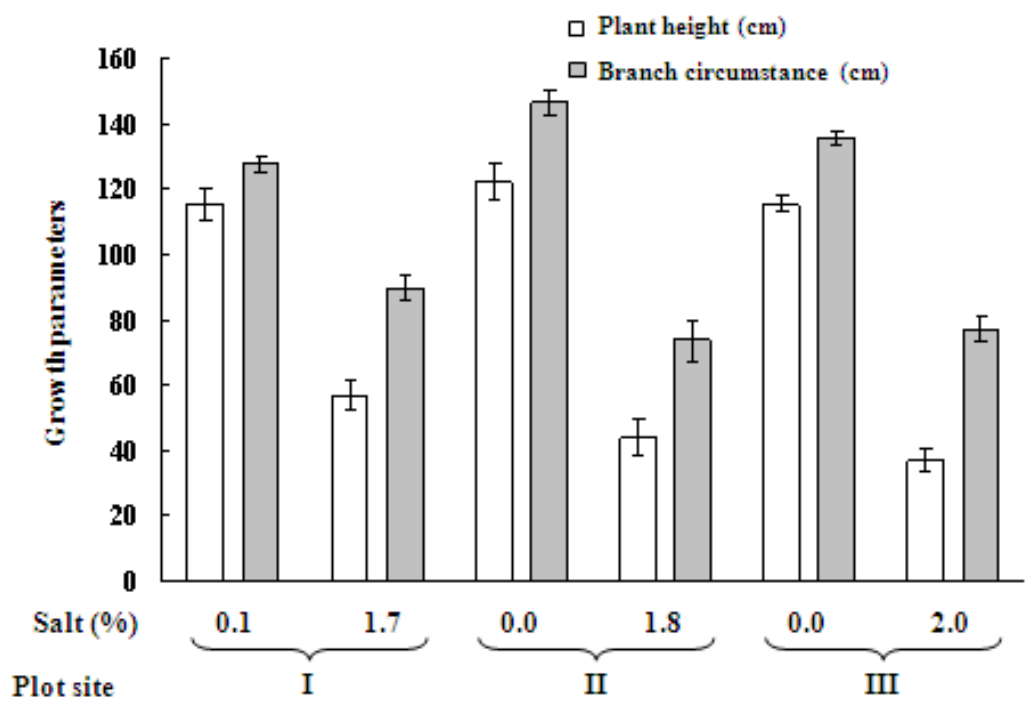

Figure 3. Plant height and circumstance diameter of eucalypt tree cultivated in different saltaffected sites for 10 months.

(A)

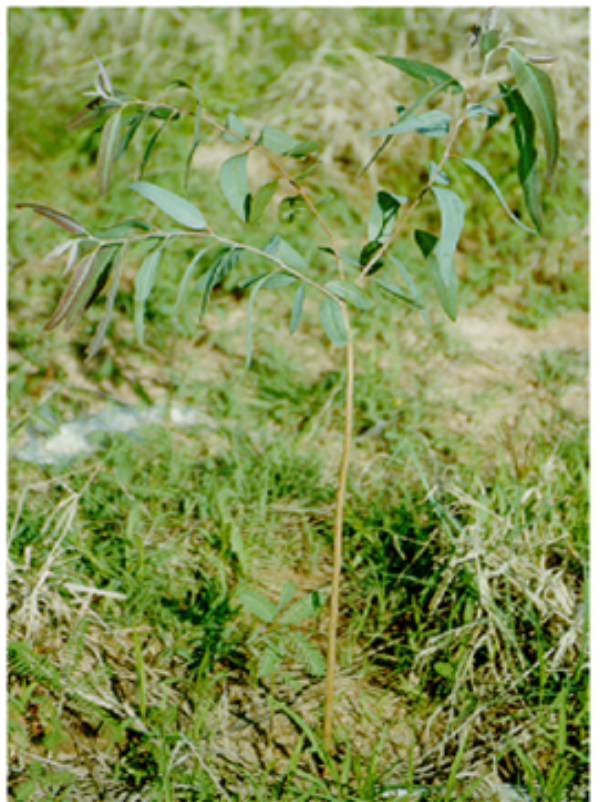

(B)

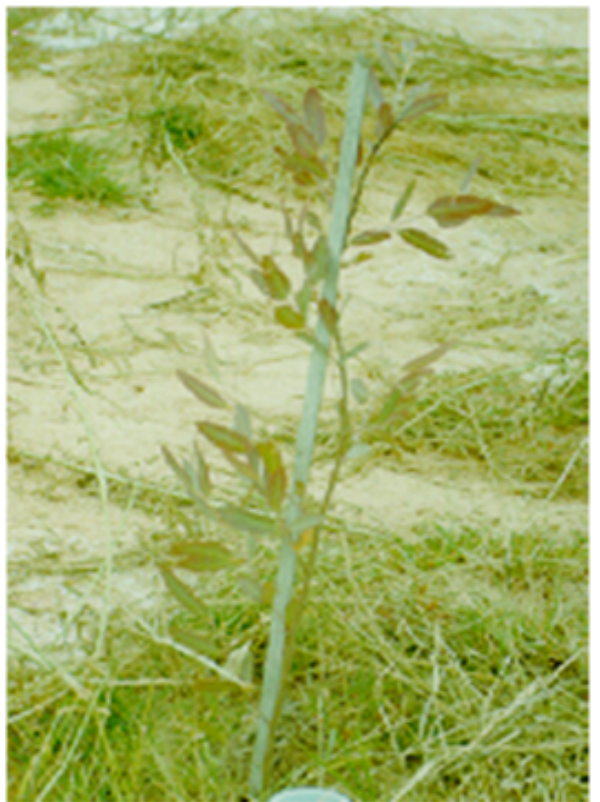

Figure 4. Morphological characters of eucalypt tree grown under control ( $0 \%$ salt) (A) and salt affected soil (2.0\% salt) for 10 months. 
In conclusion, the eucalypt plants can be grown under salt-affected soil containing $<1.7 \%$ salt with $>30$ survival percentage. The proline accumulation, water use efficiency, pigments and photosynthetic abilities as well as overall growth performance should be applied as indicator for salt tolerant screening of eucalypt tree. Eucalypt plant species may be further planted as a potential plant species to remediate the inland salt-affected soil.

\section{Acknowledgements}

The authors are grateful to Jonathan Shore for grammatical proofing. This experiment was funded by the Siam Cement Group (SCG) and partially supported by the National Center for Genetic Engineering and Biotechnology (BIOTEC), National Science and Technology Development Agency (NSTDA).

\section{References}

Adams, M. A., A. Richter, A. K. Hill and T. D. Colmer. 2005. Salt tolerance in Eucalyptus spp.: identity and response of putative osmolytes. Plant Cell Environ. 28:772-787.

Ahmad, R. and M. H. Chang. 2002. Salinity control and environmental protection through halophytes. J. Drain. Water Manage. 6:17-25.

Bate, L. S., R. P. Waldren and I. D. Teare. 1973. Rapid determination of free proline for water-stress studies. Plant Soil 39:205-207.

Cha-um, S. and C. Kirdmanee. 2008. Assessment of salt tolerance in Eucalyptus, rain tree and Thai neem under laboratory and the field conditions. Pak. J. Bot. 40:2041-2051.

Cha-um, S., K. Mosaleeyanon, C. Kirdmanee and K. Supaibulwatana. 2003. A more efficient transplanting system for Thai neem (Azadirachta siamensis Val.) by reducing relative humidity. Sci. Asia 29:189-196.

Cha-um, S., K. Supaibulwatana and C. Kirdmanee. 2007. Glycinebetaine accumulation, physiological characterizations, and growth efficiency in salt tolerant and salt sensitive lines of indica rice (Oryza sativa L. spp. indica) response to salt stress. J. Agron. Crops Sci. 193:157-166.

Chinnusamy, V., A. Jagendorf and J. K. Zhu. 2005. Understanding and improving salt tolerance in plants. Crop Sci. 45:437-448.

Corney, H. J., J. M. Sasse and P. K. Ades. 2003. Assessment of salt tolerance in eucalypts using chlorophyll fluorescence attributes. New Forest 26:233-246.

Dale, G. and M. Dieters. 2007. Economic returns from environmental problems: Breeding salt- and drought-tolerant eucalypts for salinity abatement and commercial forestry. Ecol. Engineer. 31:175-182.

Hasegawa, P. M., R. A. Bressan, J. K. Zhu and H. J. Bohnert. 2000. Plant cellular and molecular responses to high salinity. Annu. Rev. Plant Physiol. Plant Mol. Biol. 51:463-499.

Jianfeng, Z., J. Jingmin and X. Shangjun. 2008. Planting techniques of Tamarix chinensis and its effect on saline soil remediation. IEEE doi: 978-1-4244-1748-3/08.

Kiliç, C. C., Y. S. Kukul and D. Anaç. 2008. Performance of parslane (Portulaca oleracea L.) as a salt-removing crop. Agric. Water Manage. 95:854-858.

Lichtenthaler, H. K. 1987. Chlorophylls and carotenoids: Pigments of photosynthetic biomembranes. Methods Enzymol. 148:350-380.

Loggini, B., A. Scartazza, E. Brugnoli and F. Navari-Izzo. 1999. Antioxidant defense system, pigment composition, and photosynthetic efficiency in two wheat cultivars subjected to drought. Plant Physiol. 119:1091-1099.

Maathuis, F. J. M. and A. Amtmann. 1999. K Nutrition and $\mathrm{Na}^{+}$toxicity: The basis of cellular $\mathrm{K}^{+} / \mathrm{Na}^{+}$ratios. Ann. Bot. 84:123133.

Madsen, P. A. and D. R. Mulligan. 2006. Effect of $\mathrm{NaCl}$ on emergence and growth 
of a range of provenances of Eucalyptus ciriodora, Eucalyptus populnea, Eucalyptus camaldulensis and Acacia salicina. Forest Ecol. Manage. 228:152159.

Mansour, M. M. F. and K. H. A. Salama. 2004. Cellular basis of salinity tolerance in plants. Env. Exp. Bot. 52:113-122.

Nasim, M., R. Qureshi, T. Aziz, M. Saqib, S. Nawaz, S. T. Sahi and S. Pervaiz. 2008. Growth and ionic composition of saltstressed Eucalyptus camaldulensis and Eucalyptus tereticornis. Pak. J. Bot. 40:799-805.

Qadir, M., A. Tubeileh, J. Akhtar, A. Larbi, P. S. Minhas and M. A. Khan. 2008. Productivity enhancement of salt-affected environments through crop diversification. Land Degrad. Develop. 19:429-453.

Qadir, M., J. D. Oster, S. Schubert, A. D. Noble and K. L. Sahrawat. 2007. Phytoremediation of sodic and salinesodic soils. Adv. Agron. 96:197-247.

Qadir, M. and J. D. Oster. 2004. Crop and irrigation management strategies for saline-sodic soils and water aimed at environmentally sustainable agriculture. Sci. Total Environ. 323:1-19.

Rawat, J. S. and S. P. Banerjee. 1998. The influence of salinity on growth, biomass production and photosynthesis of Eucalyptus camaldulensis Dehnh. and Dalbergia sissoo Roxb. Seedlings. Plant Soil 205:163-169.

Rockwood, D. L., A. W. Rudie, S. A. Ralph, J. Y. Zhu, and J. E. Winandy. 2008. Energy product options for Eucalyptus species grown as short rotation woody crops. Int. J. Mol. Sci. 9:1361-1378.

Rodriguez-Navarro, A. and F. Rubio. 2006. High-affinity potassium and sodium transport systems in plants. J. Exp. Bot. 57:1149-1160.
Shabala, S. N., S. I. Shabala, A.I. Martynenko, O. Babourina and I. A. Newman. 1998. Salinity effect on bioelectric activity, growth, $\mathrm{Na}^{+}$accumulation and chlorophyll fluorescence of maize leaves: a comparative survey and prospects for screening. Aust. J. Plant Physiol. 25:609616.

Sharma, B. R. and P. S. Minhas. 2005. Strategies for managing saline/alkali waters for sustainable agricultural production in South Asia. Agric. Water Manage. 78:136-151.

Shirazi, M. U., M. A. Khan, M. Ali, S. M. Mujtaba, S. Mumtaz, M. Ali, B. Khanzada, M. A. Halo, M. Rafique, J. A. Shah, K. A. Jafri and N. Depar. 2006. Growth performance and nutrient contents of some salt tolerant multipurpose tree species growing under saline environment. Pak. J. Bot. 38:13811388.

Tanji, K. K. 2002. Salinity in the soil environment. In: A. Läuchli and U. Lüttge (Eds.), pp. 21-51. Salinity: Environment Plant Molecules, Kluwer Academic Publishers, Dordrecht, The Netherlands.

Tester, M. and R. Davenport. 2003. $\mathrm{Na}^{+}$ tolerance and $\mathrm{Na}^{+}$transport in higher plants. Ann. Bot. 91:503-527.

Turner, N. C. and P. R. Ward. 2002. The role of agroforestry and perennial pasture in mitigating water logging and secondary salinity: summary. Agric. Water Manage. 53:271-275.

Woodward, A. J. and I. J. Bennett. 2005. The effect of salt stress and abscisic acid on proline production, chlorophyll content and growth of in vitro propagated shoots of Eucalyptus camaldulensis. Plant Cell. Tiss. Org. Cult. 82:189-200. 